\title{
上部消化管内視鏡検查（GIF）にて重複癌を認めた 口脘癌症例についての検討
}

\author{
田 中 懭亮赤澤登柚鳥 宏 和
}

\begin{abstract}
要旨：頭頸部癌症例では，上部消化管領域に重複癌を認めることが多い。 2003 年 1 月から 2008 年 12 月の期間に当科 で加療を行った口腔癌のうち，上部消化管内視鏡検查を施行した 133 例について検討を行った。上部消化管領域に重 複癌を認めた症例は，133 例中 16 例 $(12.0 \%)$ で，全例男性で，食道癌 12 例，胃癌 4 例であった。口腔癌部位別では， 舌癌 67 例中 9 例 $(13.4 \%)$, 下顎歯肉癌 19 例中 2 例 $(10.5 \%)$, 口底癌 18 例中 3 例 $(16.7 \%)$, 頓粘膜癌 12 例中 1 例 $(8.3 \%)$, 硬口蓋癌 2 例中 1 例 $(50.0 \%)$ に認めた。病期別では, stage I 38 例中 2 例 $(5.3 \%)$, stage II 32 例中 8 例 $(25.0 \%)$, stage III 19 例中 2 例 $(10.5 \%)$, stage IV 44 例中 4 例（9.1\%）であった。また, 喫煙歴と飲酒歴は 68 例中 12 例 $(17.6 \%)$ ，哭煙歴のみは 14 例中 4 例（28.6\%）に重複癌を認め，飲酒歴のみ 12 例と喫煙歴と飲酒歴ともにない 39 例について重複癌はなかった。食道癌は 12 例中 4 例で上皮内癌であった。

キーワード：口腔癌，重複癌，上部消化管内視鏡検查
\end{abstract}

\section{緒言}

口脘癌症例では，重複癌の発生率が高いとされており 術前検査として PET-CT や胸部 CT などで検查を行って いる。特に食道癌や胃癌といった上部消化管領域での重複 癌発症頻度が高いことが知られており ${ }^{1-7)}$, 上部消化管領 域に自覚症状がなくても，口腔癌症例に対して術前スク リーニングとして上部消化管内視鏡検査（以下 GIF）を施 行し，早期に重複癌の有無を発見することは，患者の予後 を考えた上でも極めて重要である。今回われわれは口腔扁 平上皮癌症例で，術前スクリーニングとして GIF を施行 することができた症例の中から, 術前に同時性食道癌・胃 癌を認めた症例について検討を行った。

\section{対象および方法}

2003 年 1 月から 2008 年 12 月の期間に口腔扁平上皮癌 と診断され当科で加療を行った 229 症例のうち, GIF によ るスクリーニングを施行し得た 133 例を対象とした。年齢 は, $28 \sim 82$ 歳で平均年齢は 64.3 歳であった。性別は, 男 性 96 例, 女性 37 例, 原発部位は舌 67 例, 下顎歯肉 19 例, 口底 18 例, 上顎歯肉 15 例, 頓粘膜 12 例, 硬口蓋 2 例であった。なお，同時性重複癌の基準は, Gluckman ら の診断基準 ${ }^{8)}$ である第一癌発症から 6 か月以内に検出さ れたものとしたため, 今回の検索ではすべて術前スクリー ニングであり同時性重複癌である。

兵庫県立がんセンター口腔外科（主任：赤澤 登)

〔受付 : 2011 年 1 月 31 日, 受理 : 2012 年 5 月 1 日〕
以下の項目について検討を行った。

(1)全症例での重複癌発症率と重複癌治療までの期間

(2)性別での重複癌発症率

(3)口腔癌部位別での重複癌発症率

(4)口脘癌病期別での重複癌発症率

(5)喫煙，飲酒歴の有無と重複癌発症率

口腔癌発症部位別 · 病期別での重複癌発症率, 飲酒歴 · 喫煙歴の重複癌発症率についてはカイ二乗検定を用いて評 価し，5\%以下をもって有意差有りとした。

また，当院消化器内科に依頼しているが，当院では GIF に際し狭帯域観察（NBI）内視鏡を用い，ほほ全例にヨー ド生体染色を施行している。

\section{結 果}

\section{(1)全症例での重複癌発症率と重複癌治療までの期間}

GIF を施行した 133 例中, 食道癌を 12 例 $(9.0 \%)$, 胃癌 を 4 例 $(3.0 \%)$, 胃癌・食道癌を合わせると 16 例（12.0\%） に認めた（図 1)。重複癌を認めた症例の平均年齢は 64.9 歳（55～ 78 歳）であった。また口腔癌治療から重複癌治 療までの期間は，平均 3.7 か月（1.5〜 14 か月）であった (表 1)。

\section{(2)性別での重複癌発症率}

全症例 133 例中, 男性 96 例, 女性 37 例であったが，女 性では重複癌の発症は認めなかった。一方，男性のみで比 較した場合, 食道癌発症率は $12.5 \%$, 胃癌発症率は $4.2 \%$, 合わせて $16.7 \%$ に認められた（図 1)。

(3)口腔癌部位別での重複癌発症率（表 2)

食道癌は, 舌 67 例中 7 例 $(10.4 \%)$ ，下顎歯肉 19 例中 


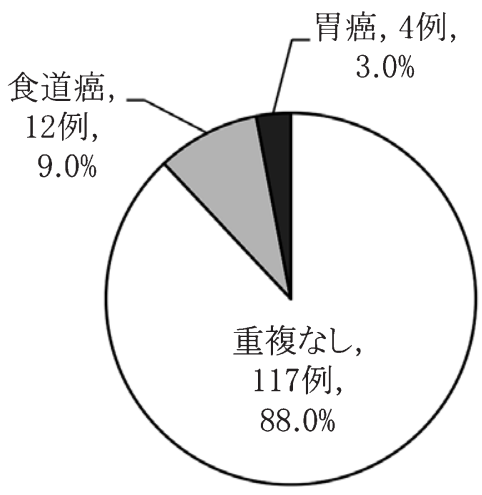

重複癌発症率

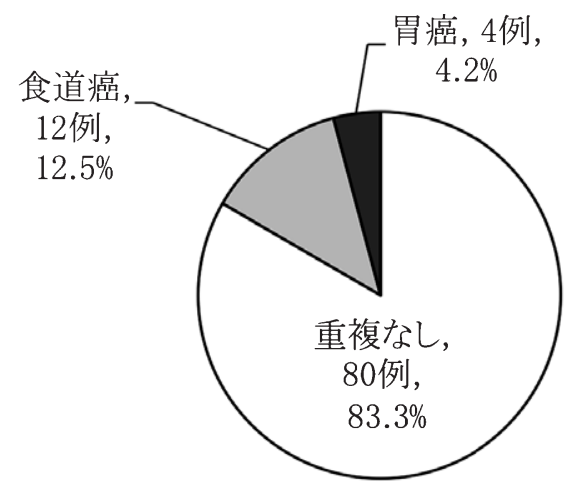

男性における重複癌発症率

図 1 重複癌発症率

表 1 重複癌を認めた症例

\begin{tabular}{|c|c|c|c|c|c|c|c|c|c|}
\hline 症例 & 年齢 & $\begin{array}{c}\text { 口腔癌原発部位 } \\
\text { (組織型) }\end{array}$ & 口腔癌病期 & $\begin{array}{l}\text { 重複癌部位 } \\
\text { (組織型) }\end{array}$ & 重複癌 T 分類 & $\begin{array}{c}\text { 重複癌の治療方法 } \\
\text { (口腔癌と重複癌の治療間隔) }\end{array}$ & 喫煙歴 & 飲酒歴 & 予後 \\
\hline 1 & 58 & 舌（SCC） & Stage II & 食道（SCC） & $\mathrm{T} 1$ & $\mathrm{ESD}^{* 1}(6 \mathrm{M})$ & $\bigcirc$ & $\bigcirc$ & 無病生存 \\
\hline 2 & 65 & 舌（SCC） & Stage II & 食道（CIS） & Tis & $\mathrm{CRT}^{* 2}(3.8 \mathrm{M})$ & 0 & 0 & 無病生存 \\
\hline 3 & 73 & 舌（SCC） & Stage IV & 食道（CIS） & Tis & 施行せず & 0 & $\times$ & 原病死 $* 4$ \\
\hline 4 & 60 & 舌（SCC） & Stage II & 食道（SCC） & $\mathrm{T} 2$ & CRT (3M) & $\bigcirc$ & $\bigcirc$ & 無病生存 \\
\hline 5 & 70 & 舌（SCC） & Stage II & 食道（SCC） & T3 & $\mathrm{OPE}^{* 3}(2 \mathrm{M})$ & $\bigcirc$ & $\bigcirc$ & 無病生存 \\
\hline 6 & 65 & 煩粘膜（SCC） & Stage I & 食道（SCC） & $\mathrm{T} 1$ & ESD $(3 M)$ & $\bigcirc$ & $\bigcirc$ & 無病生存 \\
\hline 7 & 72 & 硬口蓋（SCC） & Stage II & 食道（CIS） & Tis & ESD $(2 \mathrm{M})$ & $\bigcirc$ & $\bigcirc$ & 原病死 ※4 \\
\hline 8 & 62 & 下顎（SCC） & Stage II & 食道（SCC） & $\mathrm{T} 1$ & ESD $(3.5 \mathrm{M})$ & 0 & $\bigcirc$ & 無病生存 \\
\hline 9 & 69 & 舌（SCC） & Stage II & 食道（CIS） & Tis & CRT (2.6M) & $\bigcirc$ & $\bigcirc$ & 他病死 \\
\hline 10 & 68 & 口底（SCC） & Stage III & 食道（SCC） & $\mathrm{T} 1$ & CRT (1.5M) & $\bigcirc$ & $x$ & 無病生存 \\
\hline 11 & 60 & 口底（SCC） & Stage IV & 食道（SCC） & $\mathrm{T} 1$ & CRT $(2.5 \mathrm{M})$ & $\bigcirc$ & $\bigcirc$ & 原病死 *4 \\
\hline 12 & 70 & 舌（癌肉腫） & Stage I & 食道（SCC） & $\mathrm{T} 2$ & OPE $(3 \mathrm{M})$ & $\bigcirc$ & $\bigcirc$ & 無病生存 \\
\hline 13 & 71 & 舌（SCC） & Stage III & 胃（腺癌） & $\mathrm{T} 1$ & $\operatorname{ESD}(2 \mathrm{M})$ & $\bigcirc$ & $\bigcirc$ & 無病生存 \\
\hline 14 & 76 & 口底（SCC） & Stage IV & 胃（印環細胞癌） & $\mathrm{T} 1$ & OPE $(2 \mathrm{M})$ & $\bigcirc$ & $x$ & 原病死 ${ }^{* 4}$ \\
\hline 15 & 58 & 下顎（SCC） & Stage II & 胃（腺癌） & $\mathrm{T} 1$ & $\operatorname{ESD}(3.5 \mathrm{M})$ & $\bigcirc$ & $\bigcirc$ & 無病生存 \\
\hline 16 & 55 & 舌（SCC） & Stage IV & 胃（腺癌） & $\mathrm{T} 1$ & $\mathrm{ESD}(3.5 \mathrm{M})$ & O & $\times$ & 無病生存 \\
\hline
\end{tabular}

表 2 口腔癌部位別の食道癌・胃癌発症率 $(\mathrm{p}=0.36)$

\begin{tabular}{lcccc}
\hline \multirow{2}{*}{ 原発部位 } & \multirow{2}{*}{ 症例数 } & \multicolumn{3}{c}{ 重複癌症例数 $(\%)$} \\
\cline { 3 - 6 } & & 食道癌 & 胃癌 & 合計 \\
\hline 舌 & 67 & $7(10.4)$ & $2(3.0)$ & $9(13.4)$ \\
下顎歯肉 & 19 & $1(5.3)$ & $1(5.3)$ & $2(10.5)$ \\
口底 & 18 & $2(11.1)$ & $1(5.6)$ & $3(16.7)$ \\
上顎歯肉 & 15 & - & - & - \\
制粘膜 & 12 & $1(8.3)$ & - & $1(8.3)$ \\
硬口蓋 & 2 & $1(50.0)$ & - & $1(50.0)$ \\
\hline 合計 & 133 & $12(9.0)$ & $4(3.0)$ & $16(12.0)$ \\
\hline
\end{tabular}

1 例 $(5.3 \%)$, 口底 18 例中 2 例 $(11.1 \%)$, 上鿓歯肉 15 例 中 0 例 $(0 \%)$, 煩粘膜 12 例中 1 例 $(8.3 \%)$, 硬口蓋 2 例 中 1 例 $(50.0 \%)$ に認められた。

また, 胃癌では, 舌 67 例中 2 例 $(3.0 \%)$, 下顎歯肉 19 例中 1 例 $(5.3 \%)$, 口底 18 例中 1 例 $(5.6 \%)$ に認め, 胃 癌・食道癌を含めると, 舌 $13.4 \%$, 下顎歯肉 $10.5 \%$, 口底 $16.7 \%$, 上顎歯肉 $0 \%$, 煩粘膜 $8.3 \%$, 硬口蓋 $50.0 \%$ に認め, 比較的口底で高率に重複する結果となった。口腔癌部位 別での重複癌発症率は統計学的には有意差は認めなかった $(\mathrm{p}=0.36)$ 。

(4)口腔癌病期別での重複癌発症率（表 3)

食道癌は, stage I 38 例中 2 例 $(5.3 \%)$, stage II 32 例 
表 3 口腔癌病期別の食道癌 ·胃癌発症率 $(\mathrm{p}=0.068)$

\begin{tabular}{lcccc}
\hline \multirow{2}{*}{ 病期 } & \multirow{2}{*}{ 症例数 } & \multicolumn{3}{c}{ 重複癌症例数 $(\%)$} \\
\cline { 3 - 6 } & & 食道癌 & 胃癌 & \multicolumn{1}{c}{ 合計 } \\
\hline Stage I & 38 & $2(5.3)$ & - & $2(5.3)$ \\
Stage II & 32 & $7(21.9)$ & $1(3.1)$ & $8(25.0)$ \\
Stage III & 19 & $1(5.3)$ & $1(5.3)$ & $2(10.5)$ \\
Stage IV & 44 & $2(4.5)$ & $2(4.5)$ & $4(9.1)$ \\
\hline 合計 & 133 & $12(9.0)$ & $4(3.0)$ & $16(12.0)$ \\
\hline
\end{tabular}

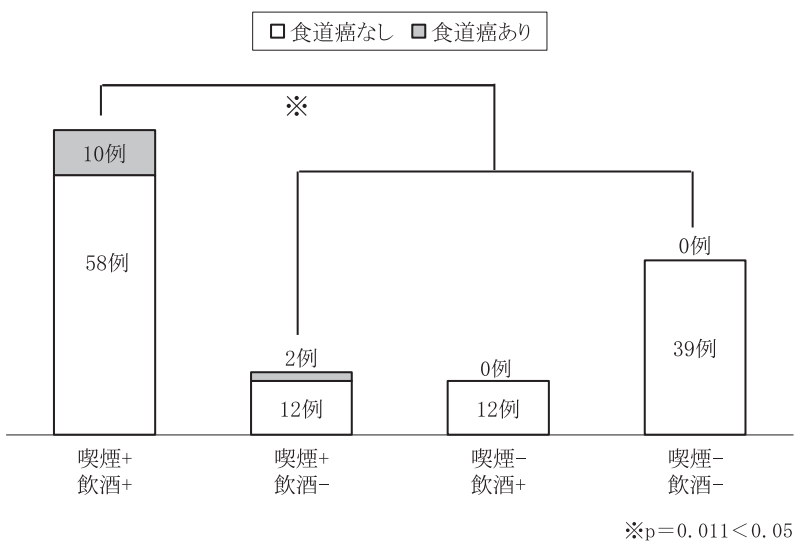

図 2 重複癌と喫煙・飲酒の関係（食道癌）

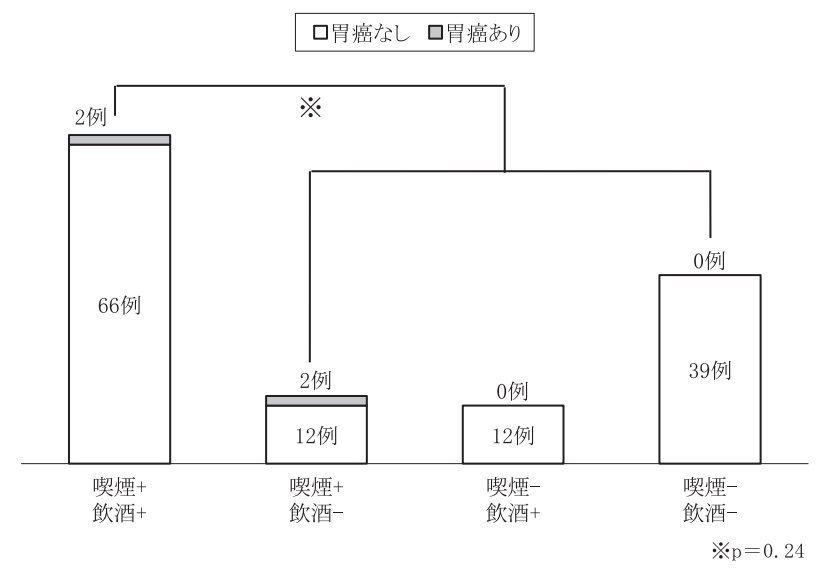

図 3 重複癌と喫煙・飲酒の関係（胃癌）

中 7 例 $(21.9 \%)$, stage III 19 例中 1 例 $(5.3 \%)$, stage IV 44 例中 2 例 $(4.5 \%)$ であった。

また胃癌では, stage I 39 例中 0 例 $(0 \%)$, stage II 32 例中 1 例 $(3.1 \%)$, stage III 19 例中 1 例 $(5.3 \%)$, stage IV 44 例中 2 例 $(4.5 \%)$ で, 両者を合わせると stage I $5.3 \%$, stage II $25.0 \%$, stage III $10.5 \%$, stage IV $9.1 \%$ で stage II で比較的高率に重複癌を認めたが, 統計学的に有意差は 認めなかった（p=0.068）。

(5)喫煙歴・飲酒歴と重複癌の関連性（図 2, 図 3)

喫煙歴・飲酒歴の有無の定義として, 契煙歴は 1 本以上 を毎日複数年の嗜好を認めた症例，また飲酒歴は日本酒に 換算して $180 \mathrm{ml}$ を毎日複数年の嗜好を認めた症例に対し て嗜好歴有りと判断した ${ }^{9)}$ 。

飲酒歴・喫煙歴の両方を有する 68 例の中で, 食道癌は 10 例 $(14.7 \%)$ で, 胃癌は 2 例 $(2.9 \%)$ で認めた。また 喫煙歴のみを有する 14 例中では，食道癌は 2 例（14.3\%） で，胃癌は 2 例 $(14.3 \%)$ に認めた。一方，飲酒歴のみを 有する症例は 12 例, 飲酒歴・喫煙歴ともに有しない症例 は39 例であったが, 両者ともに食道癌・胃癌を認めた症 例はなかった。

また，契煙歴を有する 82 例の重複癌発症率は，契煙歴 を有しない 51 例と比較して 食道癌では統計学的有意差を 認めて高かった（p=0.019<0.05）が，胃癌では有意差 を認めなかった（p=0.96）。

\section{考察}

過去の検討により，口腔・咽頭領域の癌患者は，上部消 化管領域における食道癌・胃癌の重複率が高いことがいわ れている ${ }^{1-7)}$ 。そのため, 口腔癌症例において術前スク リーニングとして GIF を施行することは必須項目であり, われわれもその重要性を説明の上，患者に同意を得られた 場合は施行している。

今回当科で検討を行った 133 例中, 食道癌・胃癌を合 わせると 16 例で, 重複癌発症率は $12.0 \%$ と他施設での結 果 ${ }^{1-7)}$ よりやや高率であるもののほほ同様であった。当院 では他施設と同じく, NBI 内視鏡を用いてほぼ全例にヨー ド生体染色を行い, 隆起性病変や潰瘍性病変のみではな く，ヨード不染域より積極的に生検を行うことにより，早 期発見につながっていると考える。その裏づけとして, 胃 癌は 4 例とも T1であり，また食道癌を認めた 12 例中 4 例が上皮内癌 (CIS), T1 が 5 例あり半数以上が早期での 発見に至っている。その上皮内癌 4 例の口腔癌の内訳は, 舌 2 例, 口底 1 例, 硬口蓋 1 例であったが, 口腔癌原発巣 との関連性は見出せなかった。

性差に関しては，重複癌 16 例はすべて男性であった。 さらに男性のみを比較した場合，重複癌発症率は $16.7 \%$ で あった。過去の報告例からも，男性に有意に重複癌を認め るという報告があり，当科における検索でも一致してい

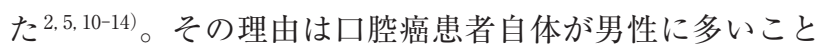
は周知の事実で，また男性に一般的に喫煙者・飲酒者が多 いことが原因ではないかと考えられるが, 自験例で重複癌 を認めた症例数も少ないことから，その理由を詳細に述べ ることは困難と思われた。 
また口底癌では, 上部消化管領域の重複癌の発症率が高 いことが言われているが9,15), 本検討では, 口底癌に関し ては, $16.7 \%$ に認めており, その点においても同様の結果 が得られた。しかし 18 例中 3 例であり, 症例数も少なく, 鹿嶋ら ${ }^{9)}$ の報告と同様に有意に口底癌で重複癌を認めると いった結論には至らなかった。

口腔癌の病期別重複癌発症率は, stage II で $25 \%$ と高率 であったが, 統計学的有意差は認めず口腔癌の進行度と重 複癌を認める確率との関連性は認めなかった。他の文献に おいては, 顎口腔領域の癌の進行度は様々で, 進行癌に多 いとされている文献や，初期癌に多いとされているもの， また進行度と相関しないと報告されているものがあり， 口 腔癌の進行度と重複癌の発症とは相関性がないと考えられ $た^{2,4,6)}$ 。

また, 今回の検索で認めた重複癌の病期は, 16 例中 11 例が stage I の症例で，山中ら ${ }^{6)}$ の報告と同様に早期発見 につながっていた。その理由として, 口腔癌の術前スク リーニングとして施行しており，患者本人の自覚症状がな いことが理由として考えられる。

喫煙・飲酒と重複癌の関連性では, 喫煙・飲酒の両方の 常用者は, いずれか一方の常用者もしくは両方の非常用者 を比較した場合, 食道癌においては統計学的有意差をもっ て重複癌を発症するリスクがあるという結果になった。他 の文献でも喫煙歴や飲酒例が重複癌の発症に関連するとい

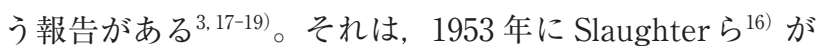
発表した, field cancerizationの概念によるものと考えら れる。口腔・咽頭・食道・胃などの連続する臓器に, 喫煙 や飲酒などの外的要因による慢性刺激が加わることによっ て, 上皮異型や癌化が広範囲に生じるといわれている。し かし，胃癌においては統計学的有意差を認めなかったが, その理由は胃癌症例が少数であることから明確にすること が難しい。今後症例を蓄積して食道癌・胃癌を詳細に比較 検討する必要があると思われる。

当科で認めた重複癌症例においては, 重複癌と口腔癌の 進行度や治療にかかる予想期間などを比較し, 当院消化器 内科と綿密に検討し優先順位を決定しているが, 検討を 行った症例すべてで口腔癌治療を優先的に行い, 口腔癌治 療から重複癌治療までの期間は，平均 3.7 か月（1.5〜 14 か月）であった。治療経過に苦虑した症例 11 の口底癌 T4aN2bM0 に扔いては, 食道癌は T1 であったため, 口 腔癌の治療を優先的に施行した。病理結果から頸部リンパ 節転移が 3 個以上認め, 口腔癌術後の放射線治療の適応と 判断したが, 口腔癌と食道癌の同時放射線療法を行った場 合, 粘膜炎など著しい患者の QOL の低下が予想されたた め, 口腔癌の術後放射線治療は施行せず, 食道癌の治療 （化学療法＋放射線療法）を開始した。その結果, 食道癌 への加療中に口腔癌の原発巣再発を認め, 食道癌治療は中
断し, 原発巣再発部の救済手術を施行するも, 再々発を認 め口腔癌での原病死に至った。この症例の反省点として, 口腔癌治療と重複癌治療を合わせると治療期間も長く, そ の治療期間中著しくQOLを低下させる結果となったため, 口腔癌と重複癌の進行度や治療期間だけで治療の優先順位 を決定することに問題があったと考える。今後重複癌を認 めた場合, それぞれの癌の根治性・予後・進行度・QOL への影響・治療方法・両方の癌の再発時の対応等を考虑に いれ，他科と十分な連携を取り，長期的な治療方針を検討 する必要がある。

\section{結語}

今回われわれは, 口腔癌症例に対して術前スクリーニン グとして GIF を施行した 133 例のうち, 重複癌を認めた 16 例（12.0\%）を経験したので，若干の文献的考察を含め 検討した。

\section{文献}

1）片桐三恵, 安藤智博, 他：口脆癌を含む多重癌 18 例の検討. 日口外誌 $40: 785-791,1994$.

2）堀内正敏, 田村嘉之, 他：頭頸部癌症例に扔ける同時多重癌 の現状と診断上の問題点. 頭頸部腫腸 $19: 319-324,1993$.

3）奥村隆司，服部賢二，他：頭頸部癌患者における上部消化管 スクリーニングの重要性について。頭頸部腫瘍 $20 ：$ 84-88, 1994.

4）山根源之，野村武史，他：頭頸部癌患者の上部消化管内視鏡 検查. 頭頸部腫瘍 $23: 89-95,1997$.

5）丁 剛, 四ノ宮 隆, 他：頭頸部癌患者に対するスクリーニ ング的食道・胃内視鏡検查 (EGF) について. 日耳鼻 103 ： 754-760, 2000.

6）山中正文, 飯田明彦, 他：内視鏡検査により上部消化管に重 複癌が検出された顎口胿領域癌患者の臨床的検討. 口科誌 $57: 303-310,2008$.

7）下山哲夫，金子貴広，他：口垫癌患者に対する上部消化管内 視鏡検查の臨床的検討. 日大歯学 $75: 327-330,2001$.

8) Gluckman, J.L., Crissman, J.D.: Survival rates in 548 patients with multiple neoplasms of the upper aerodigestive tract. Laryngoscope $93: 71-74,1983$.

9）鹿嶋光司, 有馬良治, 他：頭頸部癌患者における重複癌の検 討. 口科誌 42:316-323, 1993.

10) Kuwano, H., Morita, S., et al.: Comparison of characteristics of esophageal squamous cell carcinoma associated with head and neck cancer and those with gastric cancer. J Surg Oncol 46:107-109, 1991.

11）小川武則, 松浦一登, 他：口腔・咽頭における重複癌症例の 検討. 日耳鼻 $102 ： 1198-1206,1999$.

12）藤田一, 大橋 靖, 他：顎口胫領域に㧈ける重複癌 20 症 例の臨床的検討. 口科誌 $43: 460-465,1994$.

13）山本哲也, 片山慶馬, 他：口腔癌患者における異所性重複癌 の検討. 口科誌 $53: 161-166,2004$.

14）糸数哲郎, 古謝静男, 他 : 初診時頭頸部, 上部消化管重複癌 症例の検討. 耳喉頭頸 $68: 710-712,1996$. 
15）有地栄一郎, 神宮賢一, 他：口底癌患者における重複癌につ いて. 口科誌 $37: 654-659,1988$.

16) Slaughter, D.P., Southwick, H.W., et al.: "Filed cancerization" in oral stratified squamous epithelium; Clinical implications of multicentric origin. Cancer 6:963-968, 1953.

17）内田育宏, 小宮善昭, 他：口腔癌の重複癌発生に関する検討.
日口外誌 $44: 292-302,1998$.

18）多幾山涉, 森脇昭介, 他：食道の異型上皮, 微小癌および多 重癌に関する検討。癌の臨床 $33: 892-897,1987$.

19）中溝宗永, 鎌田信悦, 他：頭頸部癌における重複癌と喫煙飲 酒歴 人年法による解析. 日耳鼻 $96: 1501-1509,1993$. 


\title{
A clinical study of oral cancer patients with double cancer detected by upper gastrointestinal fiberscopy
}

\author{
Shinsuke Tanaka, Noboru Akazawa and Hirokazu Yutori \\ Department of Oral and Maxillofacial Surgery, Hyogo Cancer Center \\ (Chief: Dr. Noboru Akazawa)
}

\begin{abstract}
Many patients with head and neck cancers have double cancers in the upper gastrointestinal tract area. This study investigated 133 oral cancer patients who underwent upper gastrointestinal fiberscopy at the Department of Oral and Maxillofacial Surgery, Hyogo Cancer Center between January 2003 and December 2008. Double cancers were detected in the upper gastrointestinal tract area in 16 cases $(12.0 \%)$. All of those patients were male, 12 had esophageal cancer and 4 had stomach cancer. Nine of $67(13.4 \%)$ had a tumor on the tongue, 2 of 19 (10.5\%) on the lower alveolus and gingiva, 3 of $18(16.7 \%)$ on the floor of the mouth, 1 of 12 cases $(8.3 \%)$ on the buccal mucosa, and 1 of 2 cases $(50.0 \%)$ on the hard palate. Two of 38 cases were stage I, 8 of 32 cases (25\%) were stage II, 2 of 19 cases (10.5\%) were stage III, and 4 of 44 cases (9.1\%) were stage IV. Twelve of 68 patients had a history of drinking and smoking, 4 of 14 patients had only a history of smoking, and 12 patients had only a history of drinking. There were 39 patients with no history of smoking or drinking and none of these patients had double cancers in the upper gastrointestinal tract area. Carcinoma in situ was detected early in 4 patients with esophageal cancer.
\end{abstract}

Key words : oral cancer, double cancers, upper gastrointestinal fiberscopy

Requests for reprints to: Dr. Tanaka S., Department of Oral and Maxillofacial Surgery, Hyogo Cancer Center, 13-17, Kitaohji-cho, Akashi, Hyogo, 673-8558, Japan 